DOI 10.37882/2223-2982.2021.01-2.11

\title{
ОСОБЕННОСТИ ПЕРЕВОДА КОНСТРУКЦИЙ С НЕЛИЧНЫМИ ФОРМАМИ ГЛАГОЛА С ИСПАНСКОГО ЯЗЫКА НА РУССКИЙ
}

\section{SPECIFIC FEATURES OF TRANSLATION OF CONSTRUCTIONS WITH NON-INDIVIDUAL VERB FORMS FROM SPANISH TO RUSSIAN}

Yu. Palii

Summary: The present study is devoted to the issue of the usage of constructions with non-finite verb forms and theirtranslation from Spanish into Russian. The putpose of this work is to identify the peculiarities of the usage of constructions with infinitive, participle and gerund in the novel by Camilo Jose Sela «The Beehive» and the main methods of translating these constructions from Spanish into Russian. The research methodology is based on the method of comparative analysis. The results of the study show that these constructions can reflect not only the modality and aspectuality of the action, but also convey various semantic shades. The main translation methods of transferring constructions with impersonal forms of the verb into Russian are analyzed.

Keywords: non-finite forms of the verb, infinitive, participle, gerund, translation transformations, semantic development.

\author{
Палий Юлия Владимировна \\ К.п.н., доцент, Севастопольский \\ государственный университет \\ julmay19@gmail.com
}

Аннотация: Представленное исследование посвящено вопросу использования конструкций с неличными формами глагола и их перевода с испанского языка на русский. Целью данной работы является выявление особенностей употребления конструкций с инфинитивом, причастием и герундием в романе Камило Хосе Села «Улей» и основных приемов перевода данных конструкций с испанского языка на русский. Методология исследования построена на методе сравнительно-сопоставительного анализа. Результаты проведенного исследования показывают, что данные конструкции могут отражать не только модальность и аспектуальность действия, но и передавать различные смысловые оттенки. Проанализированы основные переводческие приемы передачи конструкций с безличными формами глагола на русский язык.

Ключевые слова: неличные формы глагола, инфинитив, причастие, герундий, переводческие трансформации, смысловое развитие.

полнительных слов или предложений при переводе на русский язык. Таким образом, это позволяет говорить о трудностях при переводе, связанных, в том числе, и с конструкциями с неличной формой глагола.

Целью представленного исследования является выявление особенностей употребления конструкций с неличными формами глагола в романе Камило Хосе Села «Улей» и основных приемов перевода данных конструкций с испанского языка на русский.

Методология работы построена на методе сравнительно-сопоставительного анализа.

\section{$* * *$}

В настоящее время большая часть испанских грамматик ссылается на определение глагола данное Королевской Академией Испании. «Глагол - это главная часть предложения, которая служит для обозначения сущности, существования, действия, страдательности и утверждения, касающихся всех одушевленных и неодушевленных объектов, а так же для обозначения свойств, которыми эти объекты обладают, и тех, что им приписывают» $[8$, с. 8].

Глагол в испанском языке также является источником 
образования его неличных форм: инфинитива, герундия и причастия. В сочетании с другими, определенными глаголами и предлогами, данные безличные формы образуют конструкцию, которая может отражать модальность, аспектуальность действия, указывать на дополнительный признак, отражать определенный смысловой оттенок.

Испанские грамматисты называют конструкции с инфинитивом, причастием, герундием перифрастическими или описательными. Наиболее популярным среди современных испанских исследователей является разделение конструкций с неличными формами глагола на модальные конструкции и аспектуальные, согласно их семантической направленности [7, с. 213].

Отечественные лингвисты, следую классификации, предложенной В.В. Виноградовым, как правило, разделяют конструкции с неличной формой глагола согласно модели их формирования, не опираясь на обязательное наличие описательности.

Рассмотрим примеры употребления конструкций с инфинитивом в романе Камило Хосе Селы «Улей».

Инфинитивная конструкция еmpezar a + infinitivo указывает на начало единичного действия.

"A Alfredo Ángulo Echevarría le tembraron las sienes vertiginosamente, como si tuviese calentura, y el corazón le empezó a latir a una velocidad desusada» [6, с. 89]. «У АльфредоАнгуло Эчеваррия застучало в висках, закружилась, как в горячке, голова, и сердче учащенно забилось» [5, с.113].

Оценив контекстуальное употребление конструкции автором, с целью передать интенсивность начавшегося действия, переводчик использует глагол «биться» в сочетании с приставкой «за», которая указывает на начало соответствующего действия.

Автор использует начинательную конструкцию romper $a+$ infinitivo, чтобы придать дополнительный оттенок внезапности действия, подчеркнув его интенсивность:

«La chica rompió a llorar sin saber por que» [6, c.17]. "Дeвочка разразилась слезами, не понимая причины своего расстройства» $[5$, с. 33].

При переводе используется прием экспрессивной конкретизации для сохранения адекватности высказывания.

Следующий пример с собственно начинательной конструкцией с глаголом liarse указывает на то, что одушевленный объект совершает действие неохотно, против собственной воли:

«Ayer me lié a trabajar y no salí todo el día de la casa»
[6, с.21]. «Вчера я ввязался в работу и не выходил из дому челый день» [5, с.36].

Глагол «ввязываться» указывает на то, что совершенное действие - вынужденное. При переводе данного предложения был использован метод грамматической замены, так как сочетаемость глагола «ввязываться» в русском языке ограничена, таким образом глагол trabajar был переведен существительным «работа». Данная конструкция не является популярной и часто употребляемой.

Конструкция acabar por + infinitivo указывает на то, что действие совершаемое объектом является вынужденным и неизбежным. Для передачи данного смыслового оттенка в русском языке переводчик, прибегнув к добавлению, использует наречие «наконец», которое также несет в себе значение терминативности, указывая на то, что завершенное действие было ожидаемым в связи с обстоятельствами:

«A Pepe le gusta mucho decir frases lapidarias en los momentos del mal humor. Después se va distrayendo poco a poco у acaba por olvidarse de todo» [6, с. 119]. «Когда Пепе не в духе, ему нравится отпускать вот такие короткие ругательства. Потом он отвлечется то тем, то другим, и, наконец, обо всем забудет» [5, с.136].

Практически все конструкции со страдательным причастием указывают на результат какого-либо действия или же на результат обусловленный обстоятельствами, событиями.

«Estoy casado, pero con la que usted conoce. Y esta la madre de mis hijos, esta casada tambien, pero no conmigo» [5, c. 37].

Данный пример является своеобразной игрой слов в испанском языке. Согласно правилам, глагол casarse всегда употребляется с предлогом con. Conmigo - собственное местоимение, образованное путем слияния предлога con с производной формой от местоимения me (mi). Таким образом, герой романа «Улей» сообщает об отсутствии духовной близости в его отношениях с супругой, ведь он женат на ней, но она не видит его своим мужем, испытывает чувства к другому.

Предпочтительными глаголами для образования герундиальной конструкции считаются глаголы, которые называют активное действие, глаголы движения.

«Hoy un coctel, mañana una cita, el domingo la playa, y vas distraendote, pero todos los dias son iguales» [5, c.130].

Для усиления переводчик использует разговорное наречие «все», чтобы продемонстрировать, что данный образ жизни (метод осуществления действия) является безрезультативным. 


\section{Зак^ючение}

Таким образом, конструкции с инфинитивом, причастием и герундием являются неотъемлемым элементом испанского языка и указывают на его высокий уровень развитости, а так же вносят свою лепту в процесс преобразования языка в более лаконичный, наряду с изменениями в области фонетики и лексикологии. Передача смысловых особенностей или временных конструкции с неличной формой глагола могут вызвать сложности при переводе на русский язык.

В романе Камило Хосе Селы «Улей», среди конструкций с инфинитивом наиболее частотными являются конструкции ir a + infinitivo, ponerse $a+$ infinitivo, volver a + infinitivo, tener que + infinitivo. Оттенки начинательных и собственно начинательных конструкций отличаются семантически и данный факт следует учитывать при переводе. Конструкции с глаголами empezar, comenzar, principar указывают на объективное начало действия, без субъективной оценки. В конструкциях с глаголом ponerse выражается определенная заинтересованность субъекта действия (если он одушевленный) в том, чтобы действие началось и активно осуществлялось. При неодушевленном субъекте действия конструкция указывает на более интенсивное начало действия. Глагол liar указывает на действие, начатое против воли объекта, обусловленное обстоятельствами.

Герундиальные конструкции, в отличие от конструкций с инфинитивом, не обладают многообразии глаголов, которые могут принимать участие в их формировании. Роман «Улей» считается произведением, в котором основной акцент сфокусирован на внутреннем самоощущении героев, этим объясняется небольшой процент употребления герундиальных конструкций, поскольку они чаще всего употребляются для описания динамичности действий, быстрой смены событий.

В качестве основных переводческих приемов, использованных при переводе конструкций с неличными формами глагола, можно выделить следующие: добавление, смысловое развитие, описательный перевод, антонимический перевод, грамматическая замена, опущение.

ЛИТЕРАТУРА

1. Васильева-Шведе 0.К., Степанов Г.В. Теоретическая грамматика испанского языка: Морфология и синтаксис частей речи // М.: Высшая школа, 1972.

2. Виноградов В.В. Русский язык. Грамматическое учение о слове // М.: Русский язык, 2001.

3. Комиссаров В.Н. Теория перевода: лингвистические аспекты // М.: Высш. шк, 1990.

4. Левицкая Т.Р., Фитерман А.М. Проблемы перевода // М.: Международные отношения, 1976.

5. Села K.X. [Camilo Jose Cela] Улей: Пер. с исп. Е. Лысенко // М.: Махаон, 2002.

6. Cela J.C. La Colmena // Argentina: Agro, 1951.

7. Di Tullio A. Gramática del español para maestros y profesores de Uruguay // Montevideo: ANEP PROLEE, 2012.

8. Gramática de la lengua Castellana, Del Verbo // Madrid: RAE. 1993.

(c) Палий Юлия Владимировна (julmay19@gmail.com). 